\title{
代用音声の母音音圧変動関する一知見
}

\author{
津村滋・高橋 宏明・吉田 政雄 \\ 坂本 好治・山崎隆
}

\section{Study on the Sound Pressure of Vowels in Esophageal Speech and Artificial Larynx}

\author{
Shigeru Tsumura, Hiroaki Takahashi, Masao Yoshida, \\ Koji Sakamoto and Takashi Yamasaki \\ (Osaka Med. College)
}

\begin{abstract}
To investigate the prosodic feature of artificial voice in cases of laryngectomy, the sound pressures and variances of five Japanese vowels in esophageal speech and an artificial larynx were measured and compared with same during normal speech. We found that the average pressure of the five vowels uttered by light phonation was the largest in normal speech. The pressure was smaller in cases of an artificial larynx, and smallest in esophageal speech. When uttered by subjectively rated equal loudness, the pressure variances of the same vowel in the artificial larynx were as small as in normal speech, while the variances were large in esophageal speech. The average pressure difference among the five vowels in artificial larynx was similar to that of normal speech, and was in order of $/ \mathrm{a} /, / \mathrm{o} /, \mathrm{e} /, / \mathrm{u} /$, and $/ \mathrm{i} /$. In esophageal speech, however, almost no pressure difference was observed among the five vowels. These results show that from the standpoint of sound pressure, the artificial larynx is more favorable than esophageal speech.
\end{abstract}

\section{I 緒古}

標準日本語には $5 つ$ つ音があり，それぞれ口の構えの相異により，共鳴腔インピーダンスおよ び放射インピーダンスが異なる．声門音源のエネルギーが等しい場合には，インピーダンスの高い 母音ほど口前音の音圧は小さくなる，事実われわれは主観的に同じ大きさで 5 母音を発声する事が 可能であり，その調節機構は声門下圧を一定にする事であると理解されているが，ての際には口前 音の音玨は，アオエウイの順に弱くなる．他人が漠然とこれを聴くとその音圧差がわかりにくい が, paired comparison を用いた研究によれば，聴覚的な loudness はやはり音圧の順に小さく なる。 (高橋等 ${ }^{11}$ )

会話中に出現する母音は多種多様な基本周波数や強さを有するが，平均すればやはり上述のよう な音圧関係が成立していると考えられ，したがってわれわれは母音間のてのような音圧差を無意識 のうちに会話の ‘自然性、として，聴いている筈である. 
さて喉摘者が主として用いる代用音声は，食道発声と人工喉頭である.

この両者の音声学的評価や喉摘者の使用状況などについては多くの研究があり，沢田 ${ }^{2)}$, 佐藤

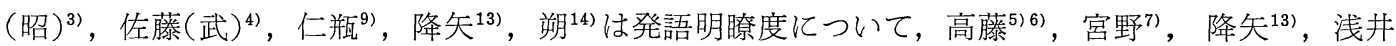
${ }^{15)}$ は音圧について報告し，また，持続時間に関しては高藤 ${ }^{516)}$ ，浅井 ${ }^{15)}$ ，音域については沢田 ${ }^{2)}$ ，高

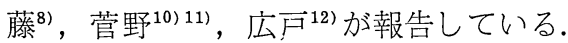

てれらを総合すると，大体の結論としては次のようになる．（1)食道音声は器具を必要としない点 に扑て，人工喉頭よりも圧倒的にすぐれている. (2)食道音声は習得に努力を要し, 発声不能な患 者もあるが，人工喉頭使用は簡単である. (3)発語明膫度には大差ないが平均すると人工喉頭がやや すぐれている。 (4)音圧，音声の持続時間，音域においては人工喉頭がすぐれている．(5)てのように 一長一短があることから両者を使いわけることが望ましいが，喉摘後まず人工喉頭を用いると食道 発声習得の意欲を失うので，まず食道発声の習得を行うべきである.

ととろで，代用音声においては intelligibility の高いととが要求されるのは論を待たないが，同 時に自然性にもすぐれていることが望ましい.

会話の自然性には種々の要素があるが，その 1 つとして上述したでとく 5 母音の音圧には差が存 在するのが自然である。 そこで代用音声においてての関係がごうであるかを知るために次のような 研究を行った。

\section{II 研 究 方 法}

\section{1. 発声者}

a. 喉摘者：表 1 亿示す 9 名. とのうち 5 名は 人工喉頻のみ, 1 名は食道発声のみ, 他の 3 名 は両種を使用したので，結局人工喉頭音声 8 種，食道音声 4 種の計 12 種である．患者の年令 は49才から75才にわたる。また 9 名中 8 名はい ずれも術後 3 年以上を経過しており，他の 1 名

(発声者 No.9) は, 術後半年であるが，日常 会話の機会が多いためその人工喉頭音声は極め て優秀である.すなわち発声者全員が日常他人 との意志疎通に不自由がない.

b. 正常者：正常男性 4 名

\section{2. 発声内容拈よび発声法}

5 母音を10個ずつ計50個をランダムに並べた リストを掲示し, 発声者はマイクの前方 $30 \mathrm{~cm}$ の 位置で， $2 \sim 3$ 秒間隔で 1 音節ずつを読み上げ た。この際，自然な高さおよび大きさとし，ま た50個を主観的に同じ大きさで発声するように 指示した。

3．音圧記録および測定法
表 |

\begin{tabular}{c|c|c|c}
\hline \hline 発声者 & 使用代用音声 & 年令 & 術後年数(年) \\
\hline №. 1 & 食·人 & 49 & 3 \\
2 & 食·人 & 55 & 7 \\
3 & 食·人 & 68 & 4 \\
4 & 食 & 69 & 6 \\
5 & 人 & 71 & 6 \\
6 & 人 & 75 & 3 \\
7 & 人 & 66 & 3 \\
8 & 人 & 67 & 3 \\
9 & 人 & 53 & 0.5
\end{tabular}

[註〕食：食道発声, 人: 人工喉頭

音声をマイクから RION. NA-51 精密騷音 計を通して high speed level recorder LROIE に記録した。この際，騒音計の特性は， $20 \mathrm{~Hz}$ 特性とし, level recorder の paper speed は $10 \mathrm{~mm} / \mathrm{s}$, pen speed は $200 \mathrm{~mm} / \mathrm{s}$ とした。読みとり方は，各々の peak 值を読 みとった。 


\section{III 研 究 結 果}

1. 正常音声

4 名の発声者について 5 母音各10個の音圧平 均抢よびその変動係数を表 2 亿示す。表 3 は 5 母音各40個の音圧平均および変動係数である. また図 I には表 2,3 の音圧を図示した。すなお ち個人差はあるが，正常音声においては 5 母音 の音圧平均は約 $83 \mathrm{~dB}$ でアオエウイの順に小さ く, 最大の/ア/と最小の/イ/との間には $6.5 \mathrm{~dB}$ の差がある. また変動係数平均は1.27である.

2. 人工喉頭音声

表 $4 ， 5$ および図Пに結果を示す。すなわち 5 母音の音圧平均は約 $79.8 \mathrm{~dB}$ で，正常音声之 同様にア，オ，エ，ウ，イの順に小さくなり， 最大の/ア/と最小の/イ/の差は $5.3 \mathrm{~dB}$ である. 変動係数平均は1.51で, 正常音声に近い.

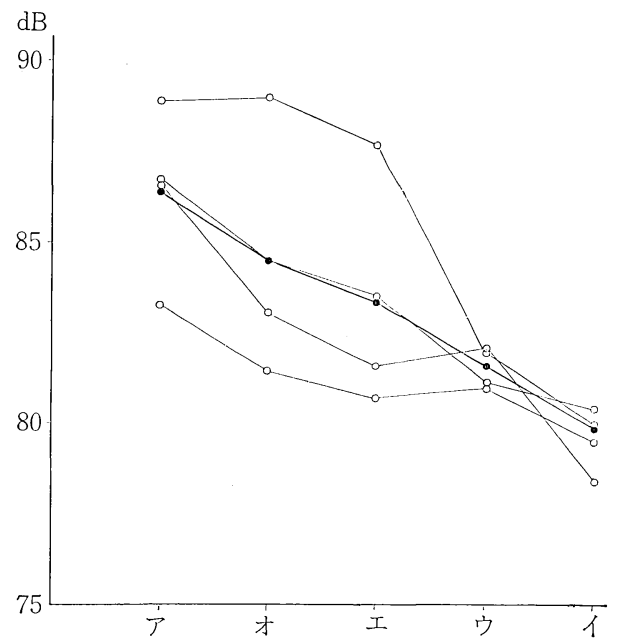

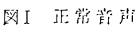

表 2

\begin{tabular}{|c|c|c|c|c|c|c|c|c|c|c|c|}
\hline \multicolumn{2}{|c|}{ 発声者 } & \multicolumn{2}{|c|}{ ア } & \multicolumn{2}{|c|}{ オ } & \multicolumn{2}{|c|}{$I$} & \multicolumn{2}{|c|}{ ウ } & \multicolumn{2}{|c|}{ 1 } \\
\hline No. & 1 & 86.7 & $(0.77)$ & 84.5 & $(0.88)$ & 83.5 & $(1.03)$ & 81.1 & $(0.55)$ & 80.4 & (1.12) \\
\hline & 2 & 83.3 & $(2.18)$ & 81.4 & (1.25) & 80.7 & (1.85) & 81.0 & $(2.27)$ & 79.5 & $(1.60)$ \\
\hline & 3 & 86.6 & $(1.34)$ & 83.1 & $(1.03)$ & 81.6 & (1.23) & 82.1 & (1.19) & 78.4 & $(0.83)$ \\
\hline & 4 & 88.9 & $(1.02)$ & 89.0 & $(0.79)$ & 87.7 & (1.31) & 82.0 & (1.34) & 80.0 & $(1.05)$ \\
\hline
\end{tabular}

表 3

\begin{tabular}{cc||c|c|c|c|c}
\hline \hline & & ア & オ & エ & ウ & イ \\
\hline 平 & 均 & 86.4 & 84.5 & 83.4 & 81.6 & 79.9 \\
$\mathrm{C}$ & $\mathrm{V}$ & 1.52 & 0.94 & 1.37 & 1.34 & 1.15
\end{tabular}

表 4

\begin{tabular}{|c|c|c|c|c|c|c|c|c|c|c|c|}
\hline \multicolumn{2}{|c|}{ 発声 者 } & \multicolumn{2}{|c|}{ ア } & \multicolumn{2}{|c|}{ オ } & \multicolumn{2}{|c|}{ 工 } & \multicolumn{2}{|c|}{ ウ } & \multicolumn{2}{|c|}{1} \\
\hline No. & 1 & 78.4 & (1.28) & 80.3 & $(0.78)$ & 77.5 & (1. 17) & 75.0 & $(0.73)$ & 71.3 & $(1.20)$ \\
\hline & 2 & 87.4 & $(2.08)$ & 83.0 & (1.51) & 82.2 & (1.62) & 78.6 & $(2.76)$ & 79.2 & $(1.02)$ \\
\hline & 3 & 80.9 & (1.29) & 80.0 & $(1.96)$ & 76.2 & $(0.68)$ & 76.3 & $(2.50)$ & 72.4 & $(2.40)$ \\
\hline & 4 & 82.4 & (1.66) & 82.5 & (1.77) & 83.0 & $(1.59)$ & 82.9 & $(1.05)$ & 81.5 & (1.04) \\
\hline & 5 & 80.0 & (1.25) & 79.4 & (1.78) & 78.2 & (1.85) & 75.3 & (1.26) & 75.6 & $(2.62)$ \\
\hline & 6 & 77.2 & $(1.22)$ & 77.6 & (1.49) & 77.9 & (1.41) & 77.1 & $(1.02)$ & 77.3 & $(2.11)$ \\
\hline & 7 & 85.8 & (1.99) & 87.0 & $(2.25)$ & 85.2 & (1.91) & 81.9 & $(0.94)$ & 81.1 & (1.65) \\
\hline & 8 & 86.2 & $(0.72)$ & 81.6 & $(0.72)$ & 81.1 & $(1.06)$ & 78.9 & $(1.04)$ & 77.4 & $(1.09)$ \\
\hline
\end{tabular}


表 5

\begin{tabular}{cc||c|c|c|c|c}
\hline & & ア & オ & エ & ウ & イ \\
\hline 平 & 均 & 82.3 & 81.4 & 80.2 & 78.3 & 77.0 \\
$\mathrm{C}$ & $\mathrm{V}$ & 1.44 & 1.53 & 1.53 & 1.41 & 1.64
\end{tabular}

表 6

\begin{tabular}{|c|c|c|c|c|c|}
\hline 発声者 & ア & オ & 工 & ウ & 1 \\
\hline No. 1 & $69.3 \quad(1.83)$ & $70.6 \quad(1.72)$ & $69.9 \quad(1.43)$ & $69.6 \quad(1.09)$ & $70.1 \quad(1.52)$ \\
\hline 2 & $82.4 \quad(2.10)$ & $82.5 \quad(1.14)$ & $80.8 \quad(2.48)$ & $80.1 \quad(1.51)$ & (1.69) \\
\hline 3 & $74.6 \quad(4.41)$ & $72.8 \quad(1.69)$ & $74.5 \quad(2.47)$ & $73.2 \quad(2.20)$ & $73.6 \quad(3.42)$ \\
\hline 4 & $70.9 \quad(3.88)$ & $71.4 \quad(5.74)$ & $72.8 \quad(2.84)$ & $73.6 \quad(1.70)$ & $74.2 \quad(3.02)$ \\
\hline
\end{tabular}

表 7

\begin{tabular}{|c|c|c|c|c|c|c|}
\hline & & ア & オ & I & ウ & 1 \\
\hline 平 & 均 & 74.3 & 74.3 & 74.5 & 74.1 & 74.1 \\
\hline $\mathrm{C}$ & $\mathrm{V}$ & 3.05 & 2.57 & 2.56 & 1.63 & 2.41 \\
\hline
\end{tabular}

\section{3. 食道音声}

表 6，7 および図凸に結果を示す．5 母音の 音圧平均は約 $74 \mathrm{~dB}$ で，正常音声および人工喉 頭音声よりあがなり低い，ただし図】に見るご とく, 発声者 No.2 のように人工喉頭之同様の 音圧を有する例外屯ある。 5 母音間の音圧差は ほとんど見られない，さらに，変動係数平均は 2. 44で, 同一母音発声時の音圧変動が大きいて とを示す.

\section{IV 考}

人工喉頭音声は呼息を用いてゴム膜を振動せ しめ，乙の音を前方から口腔内に導くことによ って成立する．乙れに対して食道音声は食道内 に吸引あるいは曣下した空気を吐出する際に下 咽頭粘膜による代用声門を振動させることによ って生ずる音を下方から共鳴腔に導くあのであ る. 本研究の結果からこの発声機構の差が母音 の音圧におよぼす影響は，次のようにまとめら

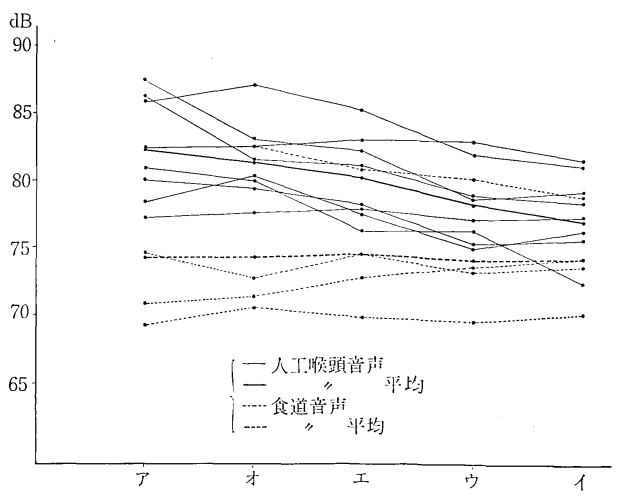

図 II 代用音声（食道音声・人工喉頭音声）

按

れる。

音压平均

自然な大きさでの発声では, 食道音声は人工 喉頭よりも音圧がかなり低く, 多人数に対して 語りかける際，あるいは騒音下の会話に执いて は不利である，食道内に貯えうる空気の量はか なり制限されて㧍り，吐出時の加圧に困難を伴 うことが主因であ万う。これに対して人工喉頭 
音声は，容積の大きい肺からの呼息を用いる点 で有利なことは自明である。

発声時音圧変動

正常音声においては，呼息調節および喉頭調 節により主観的に同じ大きさで発声するととが 可能であり，ての結果同一母音の場合には繰り 返して発声してもほぼ等しい音圧となる，勿論 熟練するほどその傾向が強い，たとえば，本研 究に扮ける正常発声者 No.1 の 5 母音別の変動 係数は 0.55 から 1.12 の間であり, 平均 0.87 之 低く, 最む変動の少ない/ウ/に㧊いては, 最大 が $81.5 \mathrm{~dB}$, 最小が $80.0 \mathrm{~dB}$ で差は $1.5 \mathrm{~dB}$ に 過ぎない.

人工喉頭音声では喉頭調節にあたる機構が失 われているが，一定の張力に固定したゴム膜の 振動であるから，振動はかなり安定している. 他方呼息調節機構は正常である。したがって

mouth piece をロにくわえるための上下顎間 距離の制限以外は比較的正常音声に近い状態で あり, 同一母音発声時の音圧変動は少ない.

ところが食道発声では吐気圧調節および代用
声門の調節の両者と屯に困難であり，乙のため の音圧変動が大きい.

5 母音音圧差

正常音声において，主観的に同じ大きさで発 声した時に，5 母音間に音圧差を生ずるととは 緒言でも述べたでとくであり，また本研究の結 果加ら明らかである.

人工喉頭音声においては，5母音の音圧関係 は正常音声に近い，上述の呼息調節之と屯に共 鳴腔形態も安定していることによるものであろ う.

これに反して食道音声では 5 母音の音圧にほ とんど差が見られない．吐気の調節および代用 声門調節が困難であると同時に，代用声門形成 のために舌運動屯多少制限され，共鳴腔形態が 不安定なととによると考えられる。会話中にお ける母音音圧が不安定であっても発語明瞭度に 影響は少ないが，ての要素に関する会話の自然 性については，人工喉頭音声の方が正常音声に 近いと言える。

\section{$\mathrm{V}$ 結 論}

正常音声 4 種，人工喉頭音声 8 種，食道音声 4 種について，5 母音発声時の音王，扣よびその変 動を測定比較した。

その結果は次のでとくである.

1. 自然な大きさで発声した場合の音圧平均は正常音声, 人工喉頭音声, 食道音声の順に小さい.

2. 主観的に同じ大きさで発声した場合, 同一母音に拈ける音圧変動は, 人工喉頭音声では正常音 声に近く変動は少ないのに反し, 食道音声では変動が大きい.

3. 5 母音間の音圧差は人工喉頭音声では正常音声之同様にアオエウイの順に小さくなるが, 食道 音声ではほとんど差がない.

武田一雄教授の御校閲を深謝する

本論文の要旨は昭和51年11月 9 日, 第21回日本音声言語医学会学術講演会および昭和52年 5 月22日 第78回日本 耳鼻咽喉科学会総会学術講演会において発表した.

\section{引用 文 献}

1) 高橋宏明, 他 : 母音勢力と loudness の関係一 Paired comparison による研究一. Audiology $19: 168 \sim 172,1976$.
2 ) 沢田公平 : 無喉頭者の発音関する実験的研究. 耳鼻臨床 $52 ： 42 \sim 72,1959$.

3 ) 佐藤昭美：人工喉頭に関する研究. 耳鼻臨床 
$53: 1018 \sim 1155,1960$.

4) 佐藤武男: 人工堠頭. 総合臨床 $13: 1177 \sim 1181$, 1964.

5 ）高藤次夫：無喉頭音声の臨床と生理. 気食学会第 12回総会シンポジウム要旨 1960.

6 ) 高藤次夫：無喉頭音声の発声機構に関する実騟的 研䆓. 日耳鼻 $56: 23 \sim 39 ， 1953$.

7 宮野和夫：人工喉頭の分析的研究. 耳喉 $33: 443$ $\sim 445,1961$.

8) 高藤次夫：無撨頭音声の音響並びに振動学的考 察. 日耳鼻56：39４5，1953.

9 ）仁瓶誠五, 他：喉摘者食道音声の語音発語明膫度 (語明度) について。気食会報 $23 ： 157 〜 163$ ， 1972.

10）管野正雄：食道発声の研究. 気食会報 $13: 135$ $\sim 151,1 \mathrm{c} 62$.
11）菅野正雄：無喉頭音声.ダイジェスト $3: 104$ $\sim 110,1960$.

12）広戸幾一郎，他：舆喉頭者の音声りハビリテーシ ョンに関する基礎的吥究. 耳臨：20：362～364, 1974.

13）降矢宜成：言語障害の語音発語明膫度（語明度） に関する研究・日耳鼻 61：1923〜1948，1958.

14）傽義一：人工喉頭の統計的観察及びその周波数分 析的研究. 耳臨 5:17〜32, 1959.

15）浅井昭三：耳鼻咽喉科悪性腫瘍に関する研究. 日 耳鼻 $61:$ 152 156, 1958.

原稿到着: 昭和 54 年 2 月 9 日
別刷請求先 : 津村滋
T5 569 大阪府高槻市大学町 $2-7$
大阪医科大学耳鼻咽喉科学教室

